
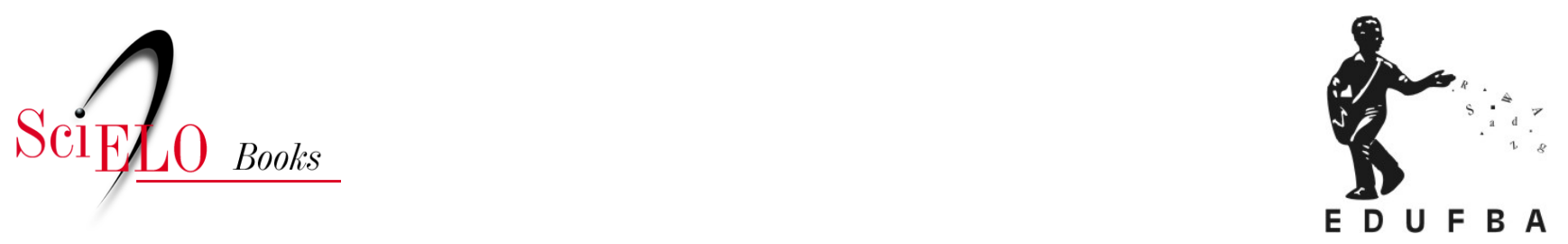

\title{
Da Glória de Jacobina às Dores de Aricobé indicações sobre o patrimônio artístico das missões franciscanas no sertão da Bahia
}

Sérgio Marcelino da Motta Lopes

\section{SciELO Books / SciELO Livros / SciELO Libros}

LOPES, S.M.M. Da Glória de Jacobina às Dores de Aricobé: indicações sobre o patrimônio artístico das missões franciscanas no sertão da Bahia. In: HERNÁNDEZ, M.H.O., and LINS, E.Á., eds. Iconografia: pesquisa e aplicação em estudos de Artes Visuais, Arquitetura e Design [online]. Salvador: EDUFBA, 2016, pp. 268-281. ISBN: 978-85-232-1861-4. https://doi.org/10.7476/9788523218614.0015.

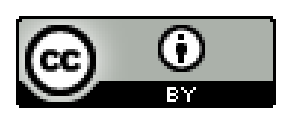

All the contents of this work, except where otherwise noted, is licensed under a Creative Commons Attribution $\underline{4.0 \text { International license. }}$

Todo o conteúdo deste trabalho, exceto quando houver ressalva, é publicado sob a licença Creative Commons Atribição 4.0. 


\section{Da Glória de}

Jacobina às Dores de

Aricobé: indicações

sobre o patrimônio

artístico das missões

franciscanas no

sertão da Bahia

Sérgio Marcelino da Motta Lopes 


\section{A missionação como instrumento do Projeto Colonizador}

o se debruçar sobre os processos de ocupação do território da
Bahia, a curiosidade não se deve esgotar com o conhecimento da
evolução histórica de Salvador e seu Recôncavo. São, de fato, etapas
importantes do processo histórico, mas a história da Bahia compreende outras dimensões igualmente significantes, como a dos sertões.

A penetração mediterrânea e a ocupação das terras do sertão, empreendimentos ainda mais laboriosos, foram também extensões da expansão colonial e do processo colonizador e consequências naturais da fascinante aventura de apossamento das "terras novas".

Apesar de terem sido as trilhas abertas pelos entradistas e bandeirantes as responsáveis pelos instantes iniciais da penetração interiorana, apenas a expansão da pecuária promoveria a interiorização mais contínua da área central baiana, transformando as incipientes veredas em caminhos permanentes, quando, de acordo com o afastamento do gado e tendo inequivocamente o Rio São Francisco como baliza natural, novos caminhos e novas pastagens iam sendo abertos.

Neste momento, contou, a empresa colonizadora, com a imperiosa e fundamental participação de religiosos de ordens diversas e com a proposta pacifica- 
dora das missões, que muito contribuíram para abrandar parte dos choques étnicos e de interesses que pontuaram o processo de colonização das terras centrais.

Desse modo, assim como os grandes coronéis do gado, agentes poderosos da grande empresa de ocupação e defesa dos sertões baianos e áreas circunvizinhas, estavam também os missionários católicos. Além das primeiras fazendas e dos povoamentos primitivos, foram também as missões evangelizadoras que deram origem às vilas, municípios, cidades, mormente nesta região do sertão sanfranciscano.

Às margens do São Francisco, existiam numerosas tribos indígenas, a maioria pertencente ao tronco cariri, algumas caraíbas e até tupis. Com elas, foram muitos os confrontos, ou por não quererem os índios ceder pacificamente as suas terras, ou por pretenderem desfrutar os gados contra a vontade dos donos. Tais lutas eram chamadas "guerras justas" e tinham por objetivo oficializar a escravização dos nativos.

Segundo Hoornaert e colaboradores (2008), pode-se distinguir quatro movimentos missionários no Brasil, obedecendo a quatro momentos da colonização portuguesa: o ciclo litorâneo, o ciclo do Rio São Francisco, o ciclo maranhense e o ciclo mineiro. Com relação ao segundo movimento, os autores escrevem que este "é condicionado pela ocupação do vasto interior brasileiro (o sertão), que foi efetuada através dos rios, sobretudo do famoso rio São Francisco, verdadeira artéria de integração brasileira nos tempos do primeiro pacto colonial". (HOORNAERT et al., 2008, p. 42-43)

\section{Os frades menores e o sertão do São Francisco ${ }^{1}$}

Embora Hoornaert e colaboradores (2008, p. 43) reconheçam que o movimento do Rio São Francisco e sertões adjacentes "tem época de vitalidade com os capuchinhos como Martinho de Nantes ${ }^{2}$ e os oratorianos", na segunda parte do século XVII, foram os frades franciscanos os primeiros a atuar sobre os gentios desses adustos sertões. Frei Basílio Röwer (1942, p. 7), um dos mais importantes historiadores dos frades menores no Brasil, conclama: "Resultaria, pois um quadro encantador se, compreendendo também os Capuchinhos, referíssemos o muito que o Brasil deve a quantos se gloriam de filhos de São Francisco".

E foi com esse espírito que aportaram aqui os primeiros frades de São Francisco: "Um grupo de oito missionários vinha com D. Pedro Álvares Cabral, em

\footnotetext{
1 Como são também chamados os religiosos franciscanos, pertencentes à Ordem dos Frades Menores, ou observantes (O.F.M., do latim Ordo Fratrum Minorum).

2 Os capuchinhos (O.F.M. cap.) integram a ordem religiosa da família franciscana e também desenvolveram intensa atividade missionária, mas estiveram notadamente circunscritos à região do baixo São Francisco, mais próxima à foz.
} 
1500, quando este, em viagem para as Índias, descobriu a terra que denominou de Vera Cruz". (RÖWER, 1942, p. 9, grifo do autor) Foram, portanto, os franciscanos os primeiros religiosos a aportar no Brasil e iniciar seus trabalhos como missionários avulsos em vários lugares, de norte a sul, até a Ordem se estabelecer definitivamente no Brasil em 1585, quando o primeiro convento foi fundado, em Olinda.

Entretanto, o raio de ação dos frades de São Francisco em muito extrapolava as espessas alvenarias de seus conventos e hospícios. Retomando o "ciclo do São Francisco" estabelecido por Hoornaert e colaboradores (2008), o período sertanejo dos franciscanos pode ser enquadrado entre os anos de 1679-1863, no qual a atenção é dirigida para as missões do Rio São Francisco, "pois no litoral não há mais indígenas senão em número muito reduzido de sorte que a pastoral se faz em relação aos moradores e seus escravos". (HOORNAERT et al., 2008, p. 55) Vale salientar que as invasões holandesas a Pernambuco tinham interrompido, em grande parte, o trabalho missionário no litoral desde 1619.

Entre 1689 e 1707, fundaram-se não menos de 20 missões entre os aborígenes, três no litoral e a maior parte na bacia do rio São Francisco, numa distância de até 300 léguas, e, além destas, mais três no atual Estado de Pernambuco. Até 1760 eram, contudo, 13 e desde então foram pouco a pouco transformadas em freguesias. A que mais tempo permaneceu sob a administração franciscana foi a de N. Sra. das Brotas ${ }^{3}$ de Joazeiro, que se tornou paróquia somente em 1840. (RÖWER, 1942, p. 76-77)

No que concerne à colonização brasileira, as ordens religiosas escapavam parcialmente das obrigações impostas pelo padroado ${ }^{4}$ e, por isso, desfrutavam de maior liberdade no contexto colonial. Além de receberem grandes quantidades de terra pelo sistema de sesmarias, também ficaram isentas do pagamento do dízimo de Deus, sendo, ainda, grandes detentoras de chãos urbanos. Foi assim com jesuítas (notórios por sua vocação às atividades comerciais), carmelitas, mercedários, dentre outros. Os franciscanos, não podendo aceitar doação de terras pelo voto de pobreza, viviam unicamente do patrimônio dos seus conventos e de esmolas.

3 Aqui, acredita-se, tenha havido erro de grafia dessa edição ou de transcrição, a partir de Frei Jaboatão, referenciado pelo autor em nota desta informação. O nome correto do orago ao qual a missão de Juazeiro foi consagrada é Nossa Senhora das Grotas, e não Brotas.

4 Por padroado, entende-se a concessão da jurisdição espiritual das novas terras descobertas, cedida pela Igreja Católica ao Estado português, estabelecendo uma combinação de direitos e deveres: a Santa Sé conferia à Coroa o privilégio de promover a cobrança e a administração do dízimo de Deus, perante o dever de provisão dos cargos, de remuneração dos religiosos e da instalação e manutenção dos templos. (HOONAERT et al., 2008, p. 33) Foi o instituto do padroado que tornou concreta essa conveniente união entre a Coroa portuguesa e a Igreja Católica, que tão fortemente caracterizou a empreitada dos descobrimentos e a configuração do império ultramarino português. 
Motivo ponderoso era, portanto, o desprendimento dos bens imóveis, não querendo os franciscanos mais do que terreno para fazer a sua casa, horta e pasto. Entretanto, quase nada se sabe da organização física destas missões. De modo geral, cada missão devia prover a sua subsistência e, para isto, cada aldeia dispunha de uma légua quadrada de terras. Além disso, muito pouco se sabe.

\section{As missões franciscanas no sertão baiano do Rio São Francisco: lacunas históricas}

Considerando esse recorte específico delineado, muitas são as lacunas em torno das missões franciscanas da Província de Santo Antônio, ${ }^{5}$ localizadas na região baiana do sertão do São Francisco.

A primeira delas está justamente na definição precisa de quais foram as missões e aldeamentos franciscanos que estavam localizados na margem direita, exatamente no lado baiano do Grande Rio, na direção de localizar, não apenas no espaço geográfico, mas também no temporal, cada um destes elementos, tanto no processo de ocupação desse mediterrâneo como nos processos econômicos e sociais que justificaram esta ocupação.

Röwer (1942, p. 43), ao discorrer sobre a expansão dos frades menores no Brasil no período colonial (entre 1585 e 1758), apresenta um cartograma que tenta localizar as missões do sertão sanfranciscano e, na impossibilidade de precisar todas as aldeias, indica suas zonas de localização aproximada: em número de 14, todas estão distribuídas em faixa contígua ao rio, aproximadamente entre o que hoje seriam os municípios baianos de Juazeiro e Bom Jesus da Lapa (Figura 1).

Já o também frade menor, Venâncio Willeke (1974, p. 88), ao enumerar todas as 25 missões da Província de Santo Antônio do Norte do Brasil (entre 1679 e 1863), se refere a pelo menos 15 localidades, que coincidem com outras tantas identificadas geograficamente por Röwer, do lado baiano do São Francisco. São elas: Missão de Nossa Senhora da Conceição de Aricobé, no atual município de Angical; Missão de Bom Jesus da Glória de Jacobina, em Jacobina; Missão de Nossa Senhora das Neves do Saí, na atual Senhor do Bonfim; Missão de São Gonçalo do Salitre, em Campo Formoso; Missão de Nossa Senhora das Grotas do Joazeiro, o atual Juazeiro; Missão de Nossa Senhora da Conceição de Pambu, na atual Abaré; Missão de Santo Antônio de Itapicuru de Cima e Missão de Nossa Senhora da Saúde de Itapicuru de Cima, em áreas que podem estar localizadas nos municípios de Itapicuru, Monte Santo ou Cipó; Missão de São

5 Por Província, entende-se o conjunto de conventos que se acham sob as ordens de um mesmo superior Provincial. (MIRANDA, 1976, p. 75) A Ordem Franciscana está, desde 1677, organizada no Brasil em duas províncias: a Província de Santo Antônio, mais antiga, com circunscrição norte; e a Província da Imaculada Conceição, com circunscrição sul. 
Francisco do Curral dos Bois e Missão de Santo Antônio da Glória do Curral dos Bois, ambas em Glória; Missão da Santíssima Trindade de Massacará, na zona rural de Cícero Dantas; Missão de Nossa Senhora das Brotas do Jeremoabo, em Jeremoabo; Missão de São João Batista de Rodelas, em Rodelas; Missão de Santo Antônio de Arguim do Massarandupió e Missão de São Francisco de Aracapá, ambas em localidades ainda não identificadas com maior precisão.

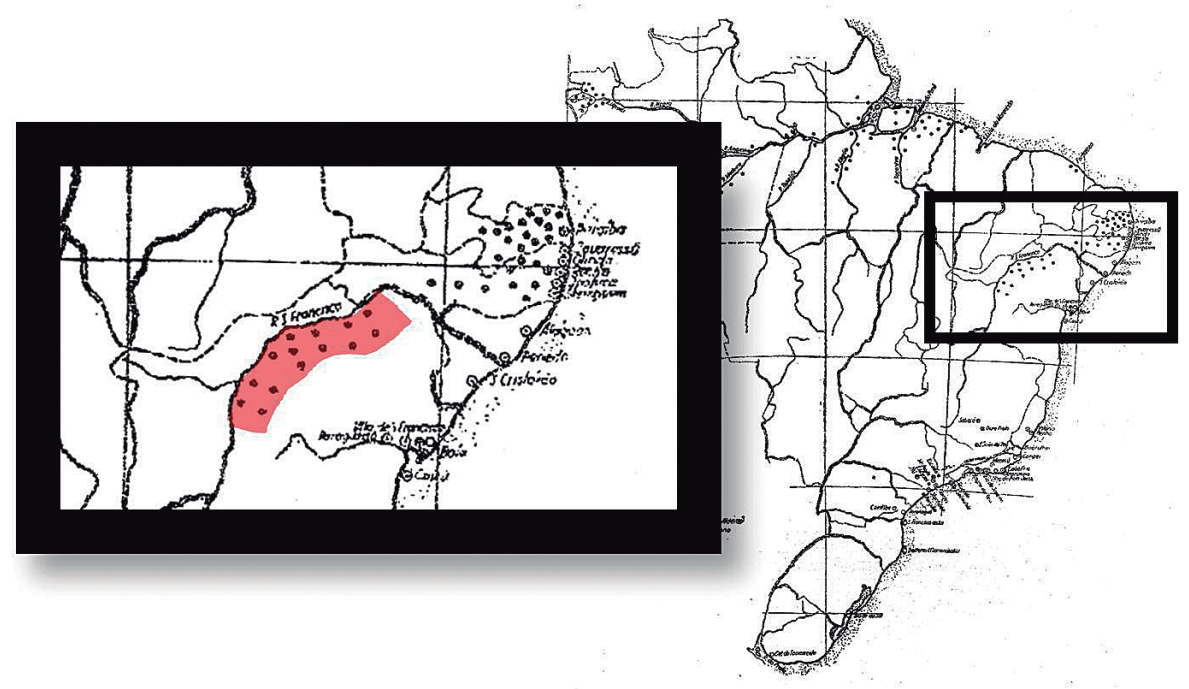

Figura 1 - As missões franciscanas no sertão baiano do São Francisco, em vermelho Fonte: Adaptado de Röwer (1942, p. 43).

Willeke (1974) também fornece informações mais específicas sobre a organização espacial dessas missões e as atividades, não apenas espirituais, que nelas se desenvolviam, lançando luz, mesmo que muito sucintamente, sobre a sua estrutura fundiária:

De modo geral, cada missão devia prover a sua subsistência. Cada aldeia dispunha de uma légua quadrada de terras. ${ }^{6}$ No entanto, esta área demonstrou-se pequena demais para resolver os problemas. Os missionários queixavam-se frequentemente sobre a invasão das terras das missões e sobre as devastações causadas pelo gado dos fazendeiros. Os índios queixavam-se de que não podiam criar gado su-

6 Em algumas realidades, como no município de Juazeiro, ainda paga-se foro anual à Igreja sobre os imóveis localizados dentro da "légua quadrada", que originalmente pertencia à missão de Nossa Senhora das Grotas, e a maior parte das glebas ainda não ocupadas nessa sede pertence, atualmente, ao patrimônio da Diocese local. 
ficiente, porque a légua quadrada não comportava mais do que oitenta famílias e uma população de mais de trezentas pessoas. A caça, seu principal alimento, minguava sempre mais. (WILLEKE, 1974, p. 107)

$\mathrm{Na}$ verdade, de todos os autores acessíveis que se debruçaram sobre a participação dos Filhos de São Francisco na formação e ocupação do território brasileiro, é Willeke o único que se detém a descrever mais sistematicamente as missões e aldeamentos, sua espacialidade. Os demais voltam-se notadamente para aspectos relativos à narração da chegada e da ação dos primeiros missionários avulsos, à evolução política e territorial das custódias e províncias e à definição dos perfis de virtude de alguns frades notórios.

Não existem, na historiografia da messe franciscana, relatos tão precisos como, por exemplo, as “Cartas Jesuítas”, sistematizadas por Serafim Leite (2006), sobre a organização daquela Ordem no território brasileiro, dando notícias detalhadas sobre os tipos de estabelecimentos através dos quais fisicamente se organizavam ${ }^{7}$ e sua composição espacial, explicitando as relações econômicas que se estabeleciam entre eles e de que forma todo este sistema se refletia na rede de aglomerações que dele resultava.

A única exceção nesse universo de informações não tão aprofundadas a respeito da organização espacial em torno das missões e aldeamentos franciscanos parece ser o "Novo orbe seráfico [...]”, do pernambucano Frei Jaboatão (1858-1862). Explique-se: absolutamente, todas as obras de vulto que se dedicam ao tema citam repetidamente notas e observações do autor e transcrevem dele trechos de relevância ao entendimento do que procuram elucidar a respeito dos Frades Menores. A obra é “amplamente baseada nos manuscritos que achou no arquivo da Província de Santo Antônio do norte do Brasil". (RÖWER, 1942, p. 12) ${ }^{8}$

Concluindo essa análise, reitera-se que a evolução e declínio das missões da margem direita do rio, do lado baiano, foi diferente daquelas da margem esquerda, pernambucana, onde houve expulsão dos missionários na época pombalina. Entretanto, também na margem baiana - onde houve, desde a segunda metade do século XVII, conflito com os fazendeiros da Casa da Torre -, é também o Marquês de Pombal o seu algoz. Com isso, tem-se apenas missões ambulantes ou volantes, com missionários peregrinos. As missões são realmente convertidas em paróquias, o que significa a maior vitória do sistema colonial sobre os esfor-

7 Os colégios, os seminários, as casas ou residências, os aldeamentos de evangelização, as fazendas e os engenhos.

8 A fonte documental a que se refere Röwer é o Arquivo Provincial Franciscano (APF), localizado no Convento de Santo Antônio, sede da Província de Santo Antônio, em Recife. Constitui-se como o maior repositório documental a respeito dos franciscanos no Brasil. 
ços missionários. O ciclo missionário sanfranciscano termina em derrota: “Os indígenas foram expulsos, ou morreram resistindo, ou foram escravizados e se tornaram vaqueiros, boiadeiros, 'cabras do sertão', caboclos, sertanejos”. (HOORNAERT et al., 2008, p. 67)

De todo esse processo, certo é que essas missões e aldeamentos franciscanos descritos tão sumariamente por Willeke e Röwer passaram a funcionar como agentes de atração para o povoamento destas áreas, originando aglomerações e formando, juntamente com a atividade pecuária e a trama de estradas e caminhos que se fortalecia na região, uma possível rede entre estes antigos núcleos sanfranciscanos na Bahia. Muito pouco ou quase nada se sabe delas e das reais influências na conformação dos núcleos urbanos a que deram origem e quais as permanências - materiais e intangíveis - resultam desse processo.

\section{Patrimônio artístico das missões: duas possibilidades de estudo, uma primeira síntese}

É bem verdade, as transformações foram muitas. Algumas desapareceram por completo, ou porque a missão se extinguiu muito cedo ou porque os aldeados abandonaram o sítio já esgotado ou fraco de caça. Outras dessas missões desenvolveram-se em cidades florescentes, sendo a capela substituída por igreja moderna e, nas palavras do próprio Willeke (1974, p. 99), "sobrevivendo como únicas testemunhas da missão, algum nome de rua ou praça”.

De fato, é necessário que se compreenda que os espaços das missões não nos chegam até a atualidade impregnados pelas noções - individuais e individualizantes - de "valor artístico", "monumentalidade" e "excepcionalidade", tradicionalmente fundamentais na definição de uma identidade nacional, manifesta numa cultura essencialmente material e de uma classe dominante descendente do branco português.

Chegam-nos enquanto espaços daqueles homens - dominadores ou dominados - e que, exatamente por serem dos homens, estão carregados de símbolos e representações. Representações estas que, por serem de natureza intangível, não são identificáveis segundo a métrica visual e estética dos conjuntos íntegros e autênticos dos núcleos históricos tradicionalmente tombados. (LOPES, 2011, p. 62) Chegam-nos enquanto "lugares". " Mas esta é outra discussão, que não se inscreve nos limites nos quais se desenvolve este trabalho.

Ao contrário, justamente a partir de suas poucas permanências materiais, identificadas até o momento, dois remanescentes merecem atenção especial, am-

9 Sucintamente, "lugar" pode ser definido como a categoria patrimonial que tem as dimensões de agregar em seu conceito mais do que a sua materialidade, de incorporar significados em torno da ação do homem na sua relação com o seu espaço: signos estes expressos nos remanescentes materiais, mas também nos aspectos do lugar que transcendem esta fisicidade. (LOPES, 2011) 
bos tendo como veículo de expressão dessas relações de poder entre opressores e subjugados, as artes plásticas.

São relevantes, primeiro, por sua natureza tão consoante com esse processo descrito nas seções anteriores: são frutos das relações de poder, nas quais todo o Projeto Colonizador - e dentro dele, o missionador - se apoiava.

Mas, também ao contrário, por sua natureza tão particular, ao expressarem justamente posicionamentos opostos nestas relações de poder inexoravelmente estabelecidas: a arte como expressão da submissão do dominado ante o dominador e a arte como expressão de transgressão.

Como manifestação da primeira postura, as pinturas decorativas do interior da capela da Missão de Bom Jesus da Glória de Jacobina, a conhecida "Igreja da Missão". Como expressão do segundo posicionamento, a peculiar imagem em madeira policromada de Nossa Senhora das Dores, proveniente da Missão de Nossa Senhora da Conceição de Aricobé e desconhecida quase por absoluto. $^{10}$

Mais do que algumas aproximações iconológicas das obras de arte em questão, e sem pretensões à crítica de cunho socioantropológico das artes enquanto veículos de manifestação das relações de poder, este trabalho pretende trazer à luz as próprias obras em questão e também lançar luz sobre as possibilidades de estudo de um acervo ainda desconhecido nas suas mais variadas dimensões, sejam as próprias artísticas e culturais, mas também as históricas, as historiográficas e, sobretudo, as patrimoniais. ${ }^{11}$

\section{Pinturas decorativas da capela da Missão de Bom Jesus da Glória de Jacobina}

No ponto mais aprazível da cidade de Jacobina, ergue-se a bicentenária capela do Bom Jesus da Glória, conhecida como 'Igreja da Missão'. Fundada em 1702, conservou-se esta aldeia sob a direção dos franciscanos até meados do século passado, permanecendo ainda hoje viva a memória do último missionário, Frei José da Encarnação, que fa-

10 Ainda sobre permanências, há também relatos de remanescentes das missões franciscanas do Saí (Senhor do Bonfim), Rodelas, Pambú (Capim Grosso) e ainda de possíveis enterramentos arqueológicos da missão de Nossa Senhora das Grotas (Juazeiro).

11 Este trabalho se baseia nas prospecções iniciais que consubstanciaram o projeto de tese intitulado As missões franciscanas da Província de Santo Antônio na Babia: do projeto colonizador aos "lugares" do sertão (LOPES, 2011), apresentado e aprovado pelo Programa de Pós-Graduação em Arquitetura e Urbanismo da Universidade Federal da Bahia (PPG-AU/UFBA) em 2012 e em pleno desenvolvimento atual. Explica-se, portanto, a relativa defasagem nas descrições dos objetos e o pouco aprofundamento de suas análises, processos estes que são também objetivos específicos da referida pesquisa e que impõem, além de pesquisa documental, a pesquisa de campo. 
lecido com fama de santo em 1859. [...] Enquanto desapareceu por completo o conventinho franciscano, outrora localizado ao lado direito da capela missionária, continua em bom estado de conservação, graças aos esforços dos monges cistercienses, encarregados da paróquia de Jacobina, e dos numerosos devotos do Bom Jesus. (WILLEKE, 1974, p. 99-100)

Esta era a situação da capela de Bom Jesus da Glória, localizada na referida missão de mesmo nome, há quase 40 anos. O relato de Willeke segue descrevendo as linhas arquitetônicas adotadas e as características do entorno, bem como o cotidiano da utilização do edifício pelos frades e índios.

Cerca de duas décadas depois deste relato, as condições da singela capela ainda eram as mesmas. É o que comprovam os registros fotográficos feitos pelo Frei João Sannig, no início da década de 1990 (Figura 2), e que fazem parte do acervo do Guardião do Convento de São Francisco da Bahia, Frei Hugo Fragoso.
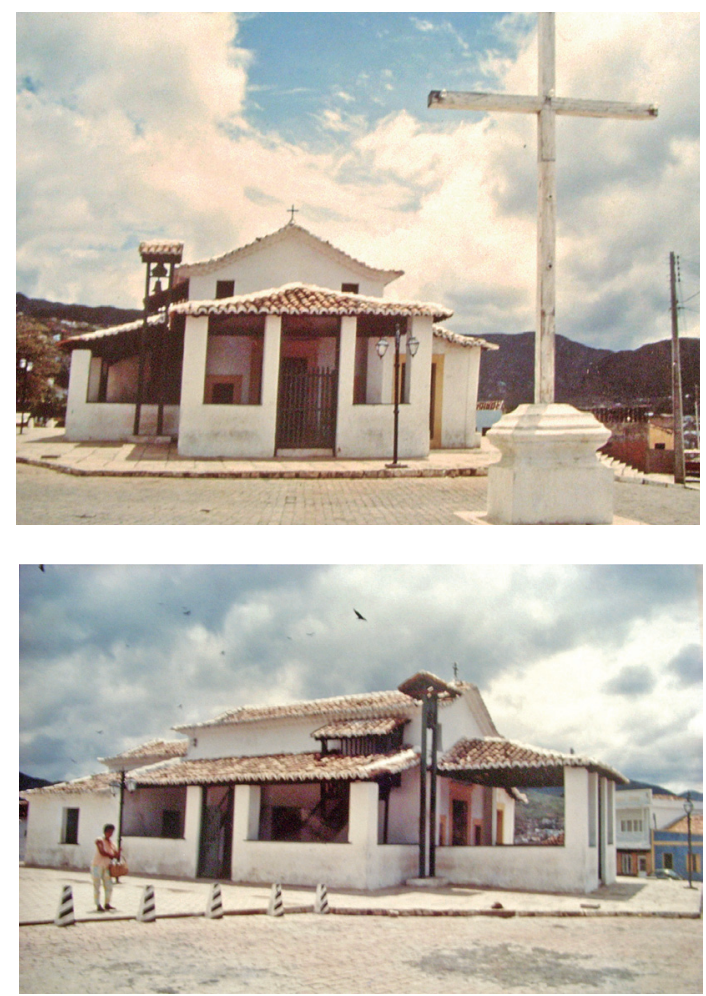

Figura 2 - Aspecto externo da "Igreja da Missão", em Jacobina: fachada frontal, com seu copiá e cruzeiro; fachada lateral 
Utilizando-se dos magníficos escritos do historiador de arquitetura Liberal de Castro, a respeito da arquitetura antiga do Ceará, pode-se afirmar, também a respeito desse edifício religioso, assim como de todos os demais deste rincão do Nordeste brasileiro, que "não se encontrarão [...] nem as elegantes igrejas paroquiais mineiras, de interiores decorados a rococó, nem os conventos magníficos de Pernambuco ou da Bahia”. (CASTRO, 1873, p. 12) No sertão nordestino, em linhas gerais, "a arquitetura antiga [...] evidenciará um caráter popular, nitidamente utilitário e claramente ecológico, mesmo nas obras administrativas ou religiosas de maior porte". (CASTRO, 1873, p. 3) Esta é a descrição que perfeitamente se aplica à antiga "Igreja da Missão".

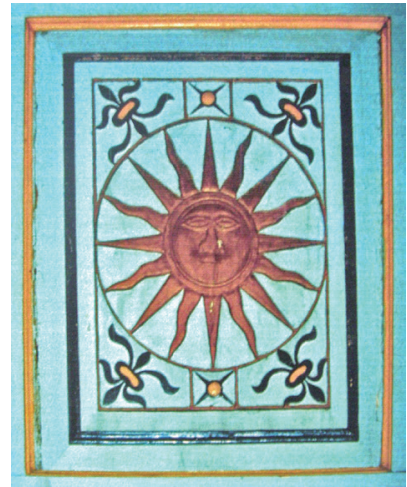

(a)

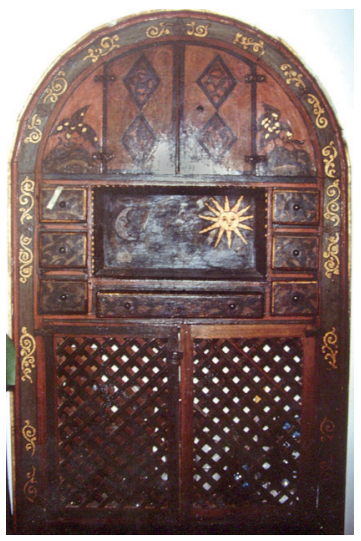

(c)

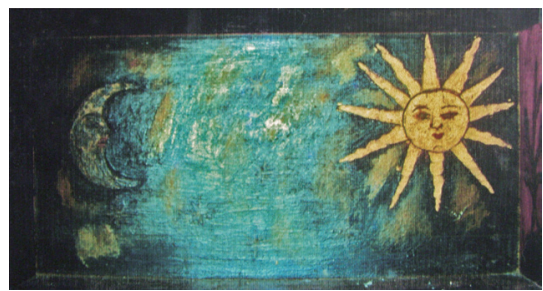

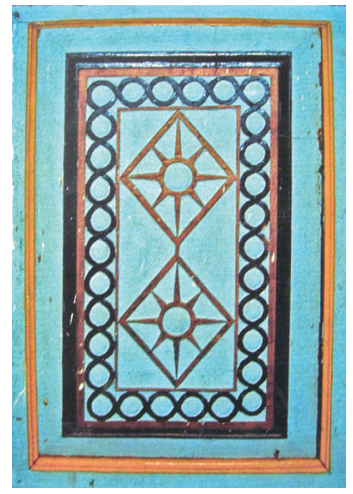

(b)

(d)

Figura 3 - Pinturas decorativas da capela de Bom Jesus da Glória:(a) retábulo em madeira policromada com motivos naturais; (b) retábulo em madeira policromada com motivos geométricos; (c) pequeno arcaz decorado; (d) detalhe do mesmo arcaz, com representações do sol e da lua, temática tipicamente franciscana

Fotógrafo: Sannig (1990). 
Ainda em termos edilícios, está igualmente a construção embebida do espírito desta Ordem que, além do desapego material resultante do voto de pobreza, reflete também o valor espiritual da "minoridade"12 franciscana, razão pela qual são, os seus espaços e construções, caracterizados pela simplicidade e singeleza.

Mas é no interior desta singela construção que se encontram os remanescentes artísticos que desvelam as relações de poder através da situação de submissão do dominado: em painéis, retábulos e outros arranjos ornamentais, a origem nativa do artista nos motivos indígenas das pinturas. São apenas relatos orais sobre esta origem. Entretanto, é inegável a identificação de uma estética claramente ligada ao universo indígena, através de expressividade que, de fato, parece traduzir pouca erudição.

Aqui, a expressão da submissão ao dominador é traduzida na utilização das mãos nativas - e de seu imaginário e expressividade - para enriquecer, através do ornamento, os espaços das práticas religiosas - mas também sociais e econômicas - do homem branco, único capaz de "despertar os descuidados, converter os pecadores e sustentar o fruto das missões”. (COUTO, 1868)

\section{Imagem de Nossa Senhora das Dores da Missão de Nossa Senhora da Conceição de Aricobé}

Dos índios aricobés, aldeados na Missão de Nossa Senhora da Conceição de Aricobé, no Médio São Francisco, na área do atual município de Angical, vem a subversão: a imagem em madeira policromada de Nossa Senhora das Dores que, segundo se conta, teria sido esculpida pelos nativos ali aldeados (Figura 4).

$\mathrm{E}$ a transgressão na ordem natural, aquela normalmente estabelecida nas tais relações de poder, não podia estar mais manifesta: na imagem de Aricobé, Nossa Senhora ampara um índio em seus braços, e não o Senhor Jesus morto!

Aqui, ainda, há uma possível imprecisão hagiográfica em relação à imagem: Nossa Senhora das Dores é representada com o coração imaculado alvejado por sete espadas (ou apenas uma), enquanto aquela que tem como atributo iconográfico, o corpo do Senhor, morto após o descimento da cruz, é Nossa Senhora da Piedade.

Mas, para além de tal imprecisão, o que mais impressiona é a possível mensagem que insiste em ultrapassar as grossas camadas de tinta e óleo que dão um brilho inadequado e desfiguram as expressões das personagens. A imagem transcende o suporte material da escultura e incide inequivocamente no observador, dando conta da real situação daqueles que sofriam - mesmo que sem esta

12 "[...] Francisco de Assis tem como lema a 'minoridade'. O que significa a 'minoridade'? Ele quis se identificar com Jesus, que se tornou menor. Com Jesus, ele se faz pequeno. [...] Por isso, coloca o nome de sua fraternidade o de Ordem dos Frades Menores. [...] Esta pedagogia dos franciscanos vai se refletir na arquitetura das missões, [e menos] na arquitetura dos conventos: sua arquitetura vai ser pobre." (Entrevista de Fragoso concedida a Sérgio Marcelino da Motta Lopes, em Salvador, em 2011) 
consciência - pela perda do que lhes identificava como semelhantes e também diferentes de outros grupos, do patrimônio herdado de seus ancestrais e que, ali, lhes era negado, da sua própria história. Merecedores que eram, portanto, dos braços piedosos da Virgem Maria. A dor, esta era a deles próprios. ${ }^{13}$

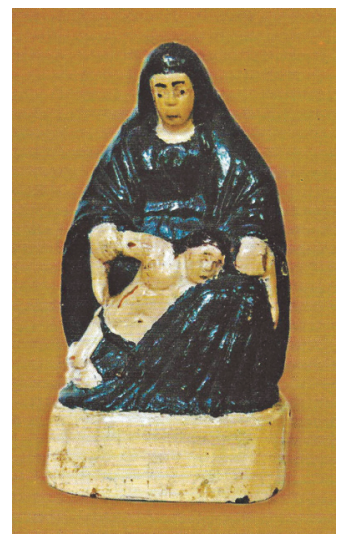

Figura 4 - Imagem de Nossa Senhora das Dores, pelos índios aricobés Fonte: Pitta (2012).

\section{Considerações finais}

Considerando a descrição dos processos de ocupação das terras mediterrâneas brasileiras e do desenvolvimento dos núcleos nestes rincões interiores, sob a égide de ação da Ordem Franciscana, esta é, em tempo, uma pequena contribuição que pretende lançar luz sobre a inequívoca riqueza do patrimônio ligado às missões. Demonstra que, muito além das tradicionais discussões em torno da "relevância" dos bens em sua corporeidade tradicionalmente considerada, há muito mais a desvelar, em termos de signos e significados.

As aproximações em iconologia aqui iniciadas dão conta das possibilidades nas quais apenas a adequada pesquisa documental será capaz de ultrapassar a mera suposição ou, até mesmo, a criação, em direção às corretas análises iconográficas, interpretação e síntese iconológicas. Demonstram, ainda, a urgente necessidade de ações efetivas de proteção, conservação e restauro. Frei Hugo Fragoso $^{14}$ ainda afirma:

\footnotetext{
13 Ainda sobre a imagem, ver: Da piedade às dores, a naturalização da santa de Aricobé (LOPES, 2013), versão ficcional, em forma de conto, da origem desta curiosa versão de Nossa Senhora das Dores.

14 Entrevista concedida a Sérgio Marcelino da Motta Lopes, em Salvador, em 2011.
} 
[...] no dizer do historiador Jaboatão - falando das missões franciscanas indigenas na Paraíba e Pernambuco -, os indios tinham uma grande aceitação e simpatia com os franciscanos, porque achavam que eles se adaptavam ao seu modo de vida, na sua 'minoridade'.

As pinturas do interior da Igreja da Missão parecem concordar com tal afirmação. A santa de Aricobé, não.

E quanto significado nesses símbolos "de paz e de bem"15...

\section{Referências}

CASTRO, J. L. de. Pequena informação relativa à arquitetura antiga no Ceará. Fortaleza: Henriqueta Galeno, 1973.

COUTO, M. J. G. Missão abreviada para despertar os descuidados, converter os peccadores e sustentar o fructo das missões. Porto: Typ. Casa de Sebastião José Pereira, 1868.

HOORNAERT, E. et al. História da Igreja no Brasil: ensaio de interpretação a partir do povo: primeira época - Período Colonial. Petrópolis: Vozes, 2008.

JABOATÃO, A. de S.M. Novo orbe seraficobrasílico... Rio de Janeiro: Typ. Brasiliense de Maximiniano Gomes Ribeiro, 1858-1862. 5 v.

LOPES, S. M. da M. As missões franciscanas da Provincia de Santo Antônio na Babia: do projeto colonizador aos "lugares" do sertão. Salvador: UFBA, 2011. (Projeto).

LOPES, S. M. da M. Aikos Proseia: da piedade às dores, a naturalização da santa de Aricobé. Chronos: arquitetura em patrimônio, Salvador, abr. 2013. Disponível em: <http://www.arq-chronos.com/2013/04/aikos-proseia-da-piedade-as-dores.html>. Acesso em: 12 fev. 2014.

LOPES, S. M. da M. Os "lugares" como dignos de preservação: a questão da preservação do patrimônio cultural em Juazeiro da Bahia. 2011. 563 f. Dissertação (Mestrado em Arquitetura e Urbanismo) - Faculdade de Arquitetura e Urbanismo, Universidade Federal da Bahia, Salvador, 2011. 2 v.

LEITE, S. História da Companbia de Jesus no Brasil. Belo Horizonte: Itatiaia, 2006. (Reconquista do Brasil, v. 201-210).

MIRANDA, M. do C. T. Os franciscanos e a formação do Brasil. Recife: EdUFPE, 1976.

PITTA, I. Os índios que habitavam a região de Barreiras. História de barreiras, [S. 1.], 2012. Disponível em: < http://www.historiadebarreiras.com/barreiras-antiga/os-indiosque-habitavam-a-regiao-de-barreiras/>. Acesso em: 24 nov. 2012.

RÖWER, B. A ordem franciscana no Brasil. Petrópolis: Vozes, 1942.

15 Referência à saudação franciscana de "Paz e Bem", que tem sua origem na descoberta e na vocação do envio dos discípulos que São Francisco descobriu no Evangelho e que ele incorpora à Regra dos Frades Menores: "o modo de ir pelo mundo". 